\title{
Prevalence of Leptospira spp. in the Kidneys of Wild Boars and Deer in Japan
}

\author{
Nobuo KOIZUMI ${ }^{1)}$, Maki MUTO ${ }^{1)}$, Akio YAMADA ${ }^{2)}$ and Haruo WATANABE ${ }^{3)}$ \\ ${ }^{1)}$ Departments of Bacteriology, ${ }^{2)}$ Veterinary Science and ${ }^{3)}$ Deputy of Director General, National Institute of Infectious Diseases, 1-23-1 \\ Toyama, Shinjuku, Tokyo 162-8640, Japan
}

(Received 13 November 2008/Accepted 26 December 2008)

ABSTRACT. We surveyed the prevalence of Leptospira spp. from 2005 to 2008 in wild boars and deer in Japan using polymerase chain reaction. Leptospiral flaB was detected in the kidneys of wild boars (positive ratio, 15.2\%; 22 of 145) from 9 prefectures and a deer $(1.1 \% ; 1$ of 94$)$ from 1 prefecture in Japan. There was no annual change in the prevalence of positive animals during the investigation period (chi-squared test, $\mathrm{p}=0.94$ ) or in the prevalence in male and female wild boars in the 2007 to 2008 season (Fisher's exact test, $\mathrm{P}=0.45$ ). The Leptospira species harbored by these animals were deduced to be L. interrogans (from 22 animals) and L. borgpetersenii (from 1 animal).

KEY WORDS: deer, Leptospira, reservoir, wild boar.

J. Vet. Med. Sci. 71(6): 797-799, 2009

Leptospirosis, which is caused by infection with pathogenic Leptospira, is an important zoonotic disease distributed worldwide $[2,8]$. Leptospires infect the proximal renal tubules of various mammals and are excreted in the urine of carrier animals. Any mammal can be a carrier and excretor of leptospires [5]. Transmission of Leptospira to mammals occurs mainly through indirect contact with water or soil contaminated with the urine of infected animals. Important reservoir animals of leptospirosis for human transmission are rats and mice that live near human habitats, domestic animals such as cattle and swine and companion animals, especially dogs. Feral animals, except rats and mice, also serve as important carriers of leptospires [2, 5]. In wild boar (Sus scrofa), antibodies against leptospires and leptospiral cells in kidney tissues have been detected $[3,6,11]$. Leptospiral antibodies have also been found in various species of deer $[3,4,9,10]$, and leptospirosis has frequently been reported in farmed deer in New Zealand [1]. We recently detected leptospiral DNA in the kidneys of wild boars and deer (Cervus nippon) in Miyazaki Prefecture, Japan [7]. The population density of wild boars and deer has recently increased in Japan. These animals migrate close to human habitats and damage agricultural crops. Thus, they may pose a risk of transmission of leptospirosis to humans in various regions of Japan if they carry leptospires. In this study, in order to assess the potential role of these feral animals as reservoirs of leptospires throughout Japan, we attempted to detect leptospiral DNA in the kidneys of wild boars and deer by polymerase chain reaction.

Kidney tissues from wild boars and deer captured in the hunting season from 2005 to 2008 were used in this study. DNA was extracted from these tissues using a DNeasy Tissue Kit (Qiagen), the leptospiral flaB gene was amplified by nested PCR [7] and the nucleotide sequences of the ampli-

\footnotetext{
* Correspondence to: Koizumi, N., Department of Bacteriology, National Institute of Infectious Diseases, 1-23-1 Toyama, Shinjuku, Tokyo 162-8640, Japan.

e-mail: nkoizumi@nih.go.jp
}

cons were then determined.

Leptospiral flaB was detected in the kidneys of wild boars (positive ratio, 15.2\%; 22 of 145) from 9 prefectures and 1 deer (1.1\%; 1 of 94) from Hokkaido, Japan (Table 1 and Fig. $1)$. The sensitivity of this assay was 1 to 2 genome equivalents per reaction (data not shown). Thus, the number of leptospires was estimated to be at least 8000 cells per gram of kidney tissue, although we did not perform a quantitative analysis. Wild boars carried leptospires more frequently than deer (Fisher's exact test, $\mathrm{p}<0.01$ ), and Leptospira-carrying wild boars are widely distributed throughout Japan (Fig. 1). Wild boars often wallow in mud for maintenance of body temperature, which may enhance the transmission of leptospires among wild boars. Because of feeding habitat differences, the nasopharyngeal mucosas of wild boars more frequently come into contact with soil than those of deer, which may also contribute to higher prevalence in wild boars. There was no annual change in the prevalence of positive animals during the investigation period (chi-squared test, $\mathrm{p}=0.94$ ). As far as the sex of the wild boars (positive males, 6/36; females, 3/25; unknown, 1/5) in the 2007 to 2008 season, there was no difference in prevalence among males and females (Fisher's exact test, $\mathrm{p}=0.45$ ). Leptospirosis in humans is transmitted by direct contact with infected animals or by exposure to water or soil contaminated with the urine of infected animals [5]. Leptospiral DNA was detected in the kidneys of these animals, indicating a risk of leptospirosis in humans, especially hunters and meat processing workers, and hunting dogs. Wild boars and deer migrate close to human habitats and damage agricultural crops, and the amount of damage has increased recently. These facts also suggest that there is a potential risk of leptospirosis in agricultural workers.

We determined the nucleotide sequences of the amplicons (accession numbers AB462457-AB462479) and obtained three sequence types (ST1-3) of the flaB gene. The Leptospira species harbored by these animals were deduced to be L. interrogans (ST1 and 2 in 22 animals) and 
Table 1. Results of flaB-PCR on wild boars and deer in Japan (2005-2008)

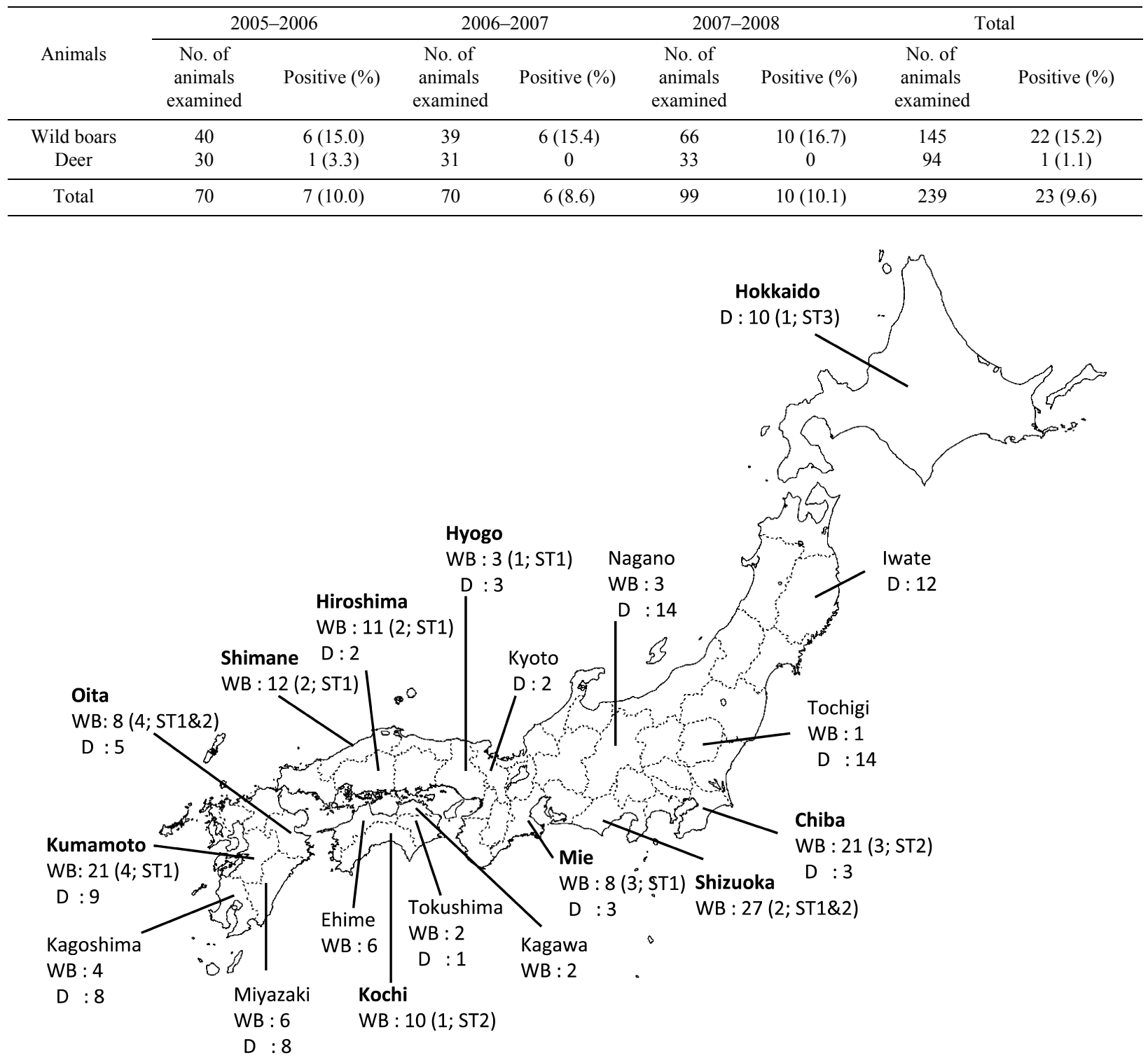

Fig. 1. Map of Japan showing the locations at which wild boars and deer were captured. The numbers and sequence types (ST 1-3) in the parentheses indicate the number of PCR-positive animals and sequence types of the flaB gene amplified, respectively. WD, wild boar; D, deer.

L. borgpetersenii (ST3 in 1 animal) by comparison of the nucleotide sequences of the $f l a B$ genes from the animals with those from reference strains (Fig. 1). The association of Leptospira serovars with their hosts is well known; for example, serovar Icterohaemorrhagiae is found in Rattus species, and serovar Hardjo is found in cattle [2]. Two flaB sequence types were detected in the kidneys of wild boars, which are widely distributed throughout Japan. This may indicate that leptospires with these sequence types are specifically associated with wild boars, although the serovars of leptospires were not determined in this study.

In conclusion, wild boars act as reservoir animals of lep- tospires in many areas in Japan. Special attention should be paid to the risk of leptospirosis in hunters, meat processing workers, and hunting dogs in Japan.

We are grateful to Dainihon Ryoyukai for providing kidney tissues from wild boars and deer. We thank H. Teraoka for technical assistance and T. Suzuki for comments in regard to this manuscript. This work was supported in part by a Health Sciences Research Grant-in-Aid for Emerging and Re-emerging Infectious Diseases (H13-Shinkou-4 and H16-Shinkou-Ippan-033) from the Ministry of Health, Labour and Welfare of Japan. 


\section{REFERENCES}

1. Ayanegui-Alcerreca, M.A., Wilson, P.R., Mackintosh, C.G., Collins-Emerson, J.M., Heuer, C., Midwinter, A.C. and Castillo-Alcala, F. 2007. Leptospirosis in farmed deer in New Zealand: a review. N. Z. Vet. J. 55: 102-108.

2. Bharti, A.R., Nally, J.E., Ricaldi, J.N., Matthias, M.A., Diaz, M.M., Lovett, M.A., Levett, P.N., Gilman, R.H., Willig, M.R., Gotuzzo, E., Vinetz, J.M.; Peru-United States Leptospirosis Consortium. 2003. Leptospirosis: a zoonotic disease of global importance. Lancet Infect. Dis. 3: 757-771.

3. Cerri, D., Ebani, V.V., Fratini, F., Pinzauti, P. and Andreani, E. 2003. Epidemiology of leptospirosis: observations on serological data obtained by a "diagnostic laboratory for leptospirosis" from 1995 to 2001. New Microbiol. 26: 383-389.

4. Deem, S.L., Noss, A.J., Villarroel, R., Uhart, M.M. and Karesh, W.B. 2004. Disease survey of free-ranging grey brocket deer (Mazama gouazoubira) in the Gran Chaco, Bolivia. J. Wildl. Dis. 40: 92-98.

5. Faine, S., Adler, B., Bolin, C. and Perolat, P. 1999. Leptospira and Leptospirosis, 2nd ed., MediSci, Melbourne.
6. Jansen, A., Luge, E., Guerra, B., Wittschen, P., Gruber, A.D., Loddenkemper, C., Schneider, T., Lierz, M., Ehlert, D., Appel, B., Stark, K. and Nöckler, K. 2007. Leptospirosis in urban wild boars, Berlin, Germany. Emerg. Infect. Dis. 13: 739-742.

7. Koizumi, N., Muto, M., Yamamoto, S., Baba, Y., Kudo, M., Tamae, Y., Shimomura, K., Takatori, I., Iwakiri, A., Ishikawa, K., Soma, H. and Watanabe, H. 2008. Investigation of reservoir animals of Leptospira in the northern part of Miyazaki Prefecture. Jpn. J. Infect. Dis. 61: 465-468.

8. Levett, P.N. 2001. Leptospirosis. Clin. Microbiol. Rev. 14: 296-326.

9. Mathias, L.A., Girio, R.J. and Duarte, J.M. 1999. Serosurvey for antibodies against Brucella abortus and Leptospira interrogans in pampas deer from Brazil. J. Wildl. Dis. 35: 112-114.

10. New, J.C. Jr, Wathen, W.G. and Dlutkowski, S. 1993. Prevalence of Leptospira antibodies in white-tailed deer, Cades Cove, Great Smoky Mountains National Park, Tennessee, USA. J. Wildl. Dis. 29: 561-567.

11. Saliki, J.T., Rodgers, S.J. and Eskew, G. 1998. Serosurvey of selected viral and bacterial diseases in wild swine from Oklahoma. J. Wildl. Dis. 34: 834-838. 